\title{
Селектор линий генерации молекулярных ИК лазеров
}

\author{
А.А. Ковалёв \\ Институт физики полупроводников им. А.В. Ржанова СО РАН \\ *E-mail: kovalev@isp.nsc.ru
}

DOI:10.31868/RFL2018.119

Непрерывные газоразрядные $\mathrm{CO}_{2}$ лазеры среднего (порядка 100 Торр) и низкого (десятки Торр) давления, в том числе лазеры на целой серии изотопов $\mathrm{CO}_{2}$, представляют собой ценный инструмент прецизионной спектроскопии [1-3]. В таких приложениях, как правило, необходимо иметь одночастотное одномодовое излучение, обладающее высокой стабильностью частоты. Проблема надежного выделения генерации на отдельном колебательно-вращательном переходе молекул представляется далекой от окончательного решения. Это связано с тем, что интенсивности линий на соседних по спектру колебательновращательных переходах сравнимы по амплитуде, и выделение одной линии требует сильного подавления генерации на ближайших соседних линиях.

В данной работе проведен критический анализ существующих, а также более или менее возможных к исполнению частотных селекторов линий генерации молекулярных лазеров ИК диапазона спектра: помещение дифракционной решетки вместо одного из зеркал резонатора [4], брэгговского зеркала, наклонного и отражательного интерферометров.

Предложен вариант селектора на основе модификации интерферометра Майкельсона, в котором одно из зеркал является отражательным фазовым интерферометром - ИМФИ. Предложенная технология изготовления ИМФИ представляется вполне доступной к исполнению для современного уровня технологии диэлектрических покрытий. Расчеты показали, что такое устройство способно обеспечить необходимое подавление соседних с выделяемой линий генерации $\mathrm{CO}_{2}$ лазера при малых потерях для выделяемой линии. Предложены два варианта перестройки по линиям генерации при одновременном надежном выделении каждой избранной линии.

\section{Литература}

[1] Patel C. K. N., Physical Review, 136, 1187 (1964)

[2] Yong Zhang and Tim Killeen, Laser Focus World, 4 November (2016)

[3] Pigeon J.J., Tochitsky S.Ya., Gong C., Josh C., Optics Letters, 39, 3246 (2014)

[4] Василенко Л.С., Дюба Н.М., Ковалёв А.А., в сб. «Перестраиваемые лазеры и их применение» под ред. В.П. Чеботаева, СО АН СССР, Институт теплофизики, Новосибирск, 105 (1988) 